\title{
Southern employers on enterprise bargaining
}

\author{
Ian McAndrew and Paul Hursthouse
}

With recently proposed amendments to the 1987 Labour Relations Act, the Government has moved another step towards embracing enterprise bargaining as a cornerstone of future New Zealand labour relations. This paper reports the opinions on enterprise bargaining of a sample of 92 employers in Otago and Southland. The employers are found to be equally divided in their preferences between enterprise bargaining and the award system. However, there is no evidence of widespread overt dissatisfaction with the functioning of the award system.

\section{Introduction}

That the New Zealand labour relations system is in a state of transition is beyond dispute. That collective bargaining at the enterprise level will be an increasingly prominent feature of the system seems ever more likely.

The Labour Government has introduced amendments to the 1987 Labour Relations Act "to ensure that where there is a desire to move towards enterprise bargaining, and where employers and employees are satisfied that that form of bargaining will benefit their interests, enterprise agreements should result" (Minister of Labour, 1990). This is to be accomplished by authorising employers of 50 or more unionised employees to initiate enterprise bargaining by invitation to the union(s) or by calling for a vote of their employees. At the same time, the 1990 National Party industrial relations policy clearly contemplates decentralising the labour relations structure to the enterprise level and beyond (National Party, 1990).

Both the New Zealand Employers Federation (NZEF) and the New Zealand Business Roundtable (NZBR) are on record in support of enterprise bargaining as a central feature of New Zealand labour relations (NZEF, 1986; NZBR, 1986). Furthermore, in the context of its concept of "industrial democracy", the New Zealand Council of Trade Unions (NZCTU) advocates wide-ranging negotiations at enterprise level, though as a supplement to, rather than as a substitute for negotiations at higher structural levels (NZCTU, 1989). And this notion has found endorsement in the report of the Committee of Inquiry into Industrial Democracy (CIID, 1989). In short, there appears to be a certain inevitability about the emergence of enterprise bargaining as a major structural feature of New Zealand labour relations in the not too distant future.

Questions linger, however, regarding both the widespread suitability of the concept to the New Zealand setting, and the enthusiasm or even readiness of unions and employers to embrace it. Of particular interest here is the widespread perception that smaller and medium-sized New Zealand firms are happy enough with the status quo and decidedly less enthused about enterprise bargaining than their larger counterparts (Minister of Labour,

Department of Management, University of Otago. The authors are grateful to Valerie Thompson for technical assistance, to Alan Geare, Pat Walsh, and an anonymous Journal referee for helpful comments, and to the interviewed employers for their participation. The research was funded by an Otago University Research Grant. 
1986; Minister of Labour, 1990; Wood, 1988, p.169; NZCTU, 1989, p.12). Major employer organisations disapprovingly share this perception. The NZEF pleads with employers to think about the issues and study the options (Marshall, 1989). The NZBR, with a narrower membership eager for change, is less patient.

A recent NZBR document somewhat testily captured that organisation's perception of employer complacency, while suggesting hopefully that the number of employers resistant to labour relations change was "probably diminishing". Those still trailing the play were portrayed as unwilling to give more attention to employee relations; as "not well placed to compete in the marketplace"; and as smugly insulated from competitive pressures. Some were seen as using award rates to avoid paying higher rates within the firm's capacity to pay, while at the other extreme, it was suggested that some larger employers used across-the-board award increases to push out smaller and more marginal competitors (NZBR, 1989, pp.11-12).

This rather uncharitable view portrays the recalcitrant employers as little more than warts on the societal bottom, selfishly clinging to the old ways, thwarting the march of progress. Yet the widespread perception persists that enterprise bargaining is a creation by and for the "New Right"; that most New Zealand employers, beyond a handful of corporate giants such as those represented by the Business Roundtable, are not enthusiastic about enterprise bargaining because it would do nothing for them; and that many are of such a size that they could not handle it even if cleansed of their alleged sins. As with all good things in the social sciences, the truth inevitably lies somewhere between these extremes.

Small and medium-sized firms are the basis of much New Zealand industry and employment, and their views on bargaining structural reform are important for the future of New Zealand labour relations. While often speculated about and sometimes maligned, those views have been rarely documented or articulated as the waves of legislative reform have rolled on by.

Earlier research by one of the authors (McAndrew, 1989) reported employer attitudes on bargaining scope and touched on their views on bargaining structure, particularly as they related to scope. That earlier study, based on a postal survey, found some limited encouragement for advocates of enterprise bargaining. Its principal finding, in terms of employer views on bargaining structure, however, was that there was a need for further documentation of those views, their patterns, and their bases. The follow-up research reported in the present paper is intended to begin to address that need.

\section{Study design and sample}

Semi-structured interviews were conducted with representatives of 92 firms in Otago and Southland. The sample was derived from earlier research, and was constructed as follows. A 1988 postal survey was mailed to the 476 member employers of the OtagoSouthland Employers Association then employing between 10 and 100 staff. Of these, 222 valid responses were received. Of those 222 employers, 117 indicated in their mailed responses that they were prepared to participate in a follow-up interview. Of the 117 , all 7 local public agencies had been absorbed by restructuring subsequent to the postal survey, 10 firms had ceased business, and 8 firms declined to participate in the interview programme.

The interviews, conducted between January, 1989 and March, 1990, averaged about one hour. Those interviewed were all senior managers, with nearly 90 percent being either owners, part owners, or chief executive officers. Almost 60 percent of the firms operated just a single place of business, and the sample was evenly split between the main centre of Dunedin and elsewhere in the region. 
In terms of "the main business" of the respondent firms and the major divisions of the New Zealand Standard Enterprise Industry Classification (NZEIC) of the New Zealand Department of Statistics, 14 of the 92 were in Agriculture, Hunting, Forestry and Fishing, 2 were in Mining and Quarrying, 20 were in Manufacturing, 14 were in Building and Construction, 22 were in Wholesale and Retail Trade and Restaurants and Hotels, 9 were in Transport, Storage and Communication, 1 was in Financing, Insurance, Real Estate and Business Services, and 10 were in Community, Social and Personal Services. All participating organisations were private sector firms.

\section{Labour relations profile}

The vast majority of the workers employed by firms in this study were covered by a union negotiated document. About a third of the firms had 90 percent of their employees covered, while more than half had between 70 and 90 percent of their employees under a union document. Workers in three-quarters of the firms were covered exclusively by national occupational awards. Less than 10 percent of the firms had experience with an enterprise agreement. The employers were dealing with an average of 3 unions. In over two-thirds of cases, the principal union on site, defined as the union representing the largest number of employees, represented 70 percent or more of the unionised employees, thereby providing a substantial base for either enterprise or industrial bargaining structures in those firms.

This picture of apparent union penetration was not matched by the reported contact respondents had with unions. In the 12 months prior to being interviewed, a third of the employers had not dealt with the principal union at all, while another third had dealt with the union just once or twice. The other third had dealt with the union more often. Union contacts mostly concerned issues of award interpretation, dismissals, or the negotiation of single issues, such as redundancy, or arose out of a general union request to meet with the workforce. Four out of 5 of these employers transacted any business with the union through paid union officials. Only about 20 percent dealt with a shop floor delegate; most of the rest were unaware of any union delegates amongst their workforces.

One-fourth of the employers believed that the union did a good job for its membership. Most of the rest had a predominantly, if mildly, negative view, more often based on the perception that the union did too little too timidly, rather than too much too aggressively. Close to one-third felt that the union simply didn't do anything.

This profile is not one of employers blocked at every turn by troublesome unions. Indeed, these employers were largely doing their own thing on employee relations matters, essentially unmolested by unions except perhaps at the rare critical point where someone lost their job for one reason or another.

For example, 85 percent paid above award rates to some or all employees some or all of the time. Most of these fixed the rates unilaterally. About one-third volunteered that they paid above the awards to counter effects of the current labour relations system, that is to equalise certain employment terms across awards or to accommodate those employees whose unions hadn't settled their awards as expeditiously as the unions representing other employees of the firm.

Most of the employers in the sample, then, were setting their own pay structures and, while pay levels generally moved with award increases, the employers unilaterally set the relationship between actual rates and award rates. In many instances, they also varied that relationship, for example by raising the level of the entire above award pay structure according to the negotiated increase in the award covering the largest number of their employees. While these above award practices are not inconisistent with the notion of awards as minimum documents, it must be said that they diminish the degree to which employees perceive their union to be responsible for the dollars in their pay packets. 
awards as minimum documents, it must be said that they diminish the degree to which employees perceive their union to be responsible for the dollars in their pay packets.

Not surprisingly, then, nearly 90 percent of the respondents indicated that they had been "usually satisfied" with the wage increases negotiated "in award negotiations over the past five years". Generally, award wages were seen as consistent with cost-of-living increases, as well as being in line with those negotiated in other awards, and within the firm's ability to pay. In the only widespread point of dissatisfaction, about one-third of the employers in the sample complained of extra payments, such as penalty rates and allowances, which were most often seen as irrelevant to the region and as serving the needs of either unions or employers in other regions, particularly Auckland. Only four employers expressed dissatisfaction with "the process of award negotiations".

Beyond wage issues, the survey revealed no union involvement, by way of either onthe-spot input or a previously negotiated document in over 90 percent of the firms on safety issues, or on the assignment of overtime opportunities (other than some protections against compulsion), or on more strategic questions of introducing new technology or otherwise changing the work process.

Union involvement aside, there was little evidence either of employee consultation practices that would be recognised by advocates of "industrial democracy" as affording employees substantial input into decision making. This is stated as a fact, rather than as a criticism. The sample firms abounded with occasions for casual contact between employees and managers. It is inherently difficult, however, to evaluate these interactions in terms of either the quality or quantity of opportunities they presented for employee input or control of managerial decisions. Suffice it to say that there were few firms in the sample in which there were any formal employee constraints on managerial decision making.

In broad summary, these employers found neither unions nor the labour relations system particularly burdensome. They enjoyed wide latitude in directing their employees and conducting employee relations matters day-to-day, restrained only by minimum standards of pay in award documents and broad behavioural parameters defined by predominantly legislative restrictions on employee dismissal, employee endangerment, and so on. In essence, the existing system did not appear to restrict them overly.

\section{Enterprise bargaining}

The central purpose of the interviews was to elicit the opinions of employers on enterprise bargaining: its advantages, its disadvantages, and how they perceived that it might work.

\section{The system defined}

A possible system of enterprise bargaining was conceptualised to all interviewed employers as follows:

(1) there would be a single union representing the entire unionised workforce of your company;

(2) the union representing your employees would be affiliated with a national union;

(3) the union and your firm would negotiate an agreement covering only the employees of your company;

(4) your workforce would be represented in these negotiations by a union official as advocate and adviser along with a small team of your employees selected by the workforce to speak for them; 
(5) your firm would be represented in these negotiations by yourself and/or other management staff, with or without the assistance of an advocate (from the employers association for example) at your discretion; and

(6) the terms of the agreement reached (the subject matter covered, the period of time covered, and the details of settlement on wages and other matters) would be as agreed between the parties, and again, would be applicable to only your firm and its employees. No other award or agreement would be applicable to your firm or its employees.

Regardless of their current arrangements, employers were asked to react to this particular concept of enterprise bargaining, assuming that it "was implemented (by a change in the law, for example), with all other factors (such as the right to strike, the personal grievance procedure, the level of union coverage and so on) remaining as they are today". The first questions concerned the possible use of an outside advocate.

Almost two-thirds of the firms indicated that they would use an outside advocate to assist in negotiations at the enterprise level. An outside advocate was seen as providing needed expertise in both the process and the issues, as well as providing a link to developments in other companies. Only eight respondents specifically mentioned the involvement of a union advocate as a basis for using an advocate themselves, although this might well have been a consideration in the widespread perceived need for expertise. A little over one-third of the firms said that they would be inclined to handle the negotiations themselves, citing their better knowledge of the company and existing good relations with their staff.

\section{Enterprise bargaining versus the national award system}

Interviewees were asked whether they saw "any advantages to your firm" in the enterprise bargaining system described "over the national award system". Perceived advantages seen by 10 or more of the employers are reported in Table 1 .

Table 1: Number of employers perceiving advantages of enterprise bargaining ( $n=92$ )

Perceived advantages

Employers

No advantages over national occupational bargaining system

Generate employment terms more tailored to local circumstances

Promote better management-staff working relationships

Allow greater company input into the bargaining process

Standardise employment terms across company workforce

Allow greater input into the bargaining process by the company's employees

Responses to this and like questions were open-ended and categorised subsequently. It is perhaps worth noting that the figures reported represent the number of interviewees 
volunteering the response, rather than the number who might concur with the responses if placed before them for reaction.

Interviewees were also asked whether they saw any disadvantages for the firm in the enterprise system versus the national award system. Disadvantages seen by 10 or more employers are reported in Table 2.

Table 2: Number of employers perceiving disadvantages of enterprise bargaining $(n=92)$

Perceived disadvantages

Employers

No disadvantages by comparison with national occupational bargaining system

Would damage management-staff working relationships

Would require additional managerial costs, duties and time

Would isolate the company from other employers

Would result in an absence of pay guidelines for company pay setting

Would increase the prospect of the company being targeted by the union

Would generate greater labour consciousness among the workforce

Having offered their opinions on the advantages and disadvantages of enterprise bargaining, interviewees were asked whether, "on balance", they felt that the enterprise system would be "better for your firm than the national award system, or not as good". The sample was almost evenly divided, with 48 employers preferring enterprise bargaining and 44 opting for the national award system. Of the 92 employers, 53 felt that enterprise bargaining would be better for their employees than the national award system.

\section{Patterns of preference}

Chi-square tests were conducted to identify any relationships between employer preference on bargaining structure and the characteristics of the sample firms. There was no statistically significant relationship between interviewee status and preference.

Of the non-labour relations characteristics, only the nature of the business bore any statistically significant relationship to preference for enterprise bargaining. There was no preference pattern associated with either the firm's number of places of business, or location within the Otago-Southland area.

Employers in the Agriculture, Hunting, Forestry and Fishing category of the NZEIC were significantly more likely, while employers in the Wholesale and Retail Trade and Restaurants and Hotels category were significantly less likely to prefer enterprise bargaining than the remaining employers in the sample $(p<.003)$.

There was no statistically significant correlation between preference for enterprise bargaining and the number of unionised employees in the firm. Indeed, perhaps 
unexpectedly, 60 percent of those with 25 or less unionised employees favoured enterprise bargaining, compared with only about 40 percent of those with more than 25 unionised employees. This result suggests that the Government's recently introduced legislation extending the right to initiate enterprise bargaining to only those employers with 50 or more unionised employees ought perhaps to be rethought.

\section{Union representation and relations}

There was a weak but statistically significant relationship between preference for enterprise bargaining and the percentage of a firm's employees covered by union negotiated documents. Specifically, employers with less than 85 percent of their employees covered were more likely to prefer enterprise bargaining than those with 85 percent or more of their employees under union jurisdiction $(p<.03)$.

There were no statistically significant relationships between preference for enterprise bargaining and the number of unions currently in the plant, or the principal union with which the firm dealt, or the percentage of unionised employees represented by the principal union, or whether the principal union representative was a paid official or a shop floor delegate. There were, however, some interesting and suggestive numbers in several of these respects.

For example, isolating the three unions that were the principal union in 10 percent or more of the sample establishments, preference for enterprise bargaining was expressed by 60 percent of employers dealing principally with the Drivers Union, by almost 70 percent of employers dealing principally with the Engineers Union, by only about 20 percent of those dealing principally with the Shop Employees Union, and by about half of the remaining employers dealing principally with one of the other 27 unions that showed up in the sample.

Or again, while not statistically significant, it is of interest that almost three-quarters of employers who dealt primarily with a shop floor union delegate preferred enterprise bargaining, whereas less than one-half of those dealing primarily with a paid union official did so. Similarly, a higher percentage of those employers who dealt regularly with the principal union preferred enterprise bargaining than was the case among employers who seldom or never had contact with the union. Those dealing regularly with unions were also more likely to view the union positively ( $p<.03)$, as were those dealing with a shop floor delegate $(\mathrm{p}<.005)$. As will be discussed later, these ostensible relationships appear to be derived from more primary ones.

\section{Award coverage and involvement}

There were no patterns of preference for enterprise bargaining associated with expressed satisfaction or dissatisfaction with either award wage increases over the preceding five years or the perceived opportunities for input and involvement in the award process. But one factor that did prove to be significant in relation to employer preference for enterprise bargaining was the current pattern of award and/or agreement coverage.

Those employers whose unionised employees were covered exclusively by national or near-national awards were significantly less likely to prefer enterprise bargaining than those whose employees were covered exclusively by regional awards, exclusively by plant agreements, or by some combination of documents that included regional awards and/or plant agreements $(\mathrm{p}<.02)$. Those employers with some or all employees currently under an enterprise agreement were significantly more likely to prefer enterprise bargaining $(p<.005)$. Indeed, all of the employers with a plant agreement covering some or all employees expressed a preference for enterprise bargaining over the national award system. 


\section{Current decision-making practices}

There were no statistically significant relationships found between preference for enterprise bargaining and current decision-making practices. For example, employers presently paying above award rates were no more likely to prefer enterprise bargaining than those paying the award rates. Further, while some of the reasons cited for paying above award rates, such as the equalisation of terms across the workforce, suggested an enterprise approach, they were not reliable predictors of preference. Likewise, there was no relationship between bargaining structure preference and the manner in which above award payments were determined. As a minor, but perhaps noteworthy exception, each of the small number of employers who had fixed above award rates through informal second tier union negotiations preferred enterprise bargaining over the national award system.

In a similar pattern, close to 90 percent of those employers who indicated that they would presently involve the union in resolving safety concerns preferred enterprise bargaining, compared with less than half of those who would not involve the union. Or again, each of the small number of employers who indicated that they would negotiate with the union(s) over the decision to introduce new technology or otherwise change the production process expressed a preference for enterprise bargaining. Beyond these footnotes, however, there were no relationships between bargaining structure preference and current decision making procedures.

\section{Characteristics of enterprise bargaining}

As might be expected, there was a certain cohesion evident in the responses to the several questions directly focused on enterprise bargaining. For example, those preferring enterprise bargaining were significantly less likely to want to use an outside advocate to assist in the bargaining ( $p<.007)$. Half of those opting for enterprise bargaining would use an advocate at that level, whereas three-quarters of those preferring the national award system would use an advocate if they were required to negotiate at enterprise level.

Employers preferring enterprise bargaining over the national award system were very much more likely to believe that enterprise bargaining would also be better for their employees than those preferring the national award system $(p<.00001)$.

Higher percentages of those citing improved productivity (100 percent), better union understanding (100 percent, better staff relations ( 94.7 percent), and terms tailored to the needs of the company ( 82.6 percent) as perceived advantages of enterprise bargaining preferred that system "on balance" than was the case among those citing other, presumably less persuasive advantages. On the other side of the ledger, higher percentages of those who cited a reduction in informal managerial discretion (100 percent), higher labour consciousness (90.9 percent) or union presence in the plant (85.7 percent), demands on management time (84.2 percent), and potential damage to staff relations (81.0 percent as perceived disadvantages of enterprise bargaining opted for the national award system than was the case among those seeing other disadvantages in a system of enterprise agreements.

Finally, there was no relationship between an employer's preference for enterprise bargaining and the willingness to negotiate either safety rules or overtime assignment rules at enterprise level. In other words, employers preferring the national award system were as willing as employers preferring the enterprise system to negotiate these issues at enterprise level, in the event an enterprise bargaining system was implemented. 


\section{Discussion}

A small majority of the employers in the sample indicated that they would opt for an enterprise bargaining system and out of the national award system if given the opportunity. Their reasons for doing so, however, would appear to be based on something other than a groundswell of discontent with the existing system. The survey data reveal little overt dissatisfaction with existing patterns of interaction between employers and unions, and relatively little dissatisfaction with the outcomes of the existing system.

Few of these employers have any complaints about the award negotiations process. Most expressed the view that the opportunities to be involved are there if they choose to take them. Additionally, no statistically significant relationships were found between preference for enterprise bargaining and any of the union variables. While some of these employers find the union irritating, most simply do not see unions as threatening or unduly restrictive. Finally in terms of processes, there was no relationship between preference for enterprise bargaining and current decision making practices. In short, there is no evidence that a negative reaction to the way in which employers and unions interact in the current system is motivating the preference for enterprise bargaining by more than half the employers in the sample.

With one exception, there is no evidence to suggest that active dissatisfaction with the outcomes produced by the existing system are motivators for a change to enterprise bargaining either. Nine out of 10 of the employers have no complaints with the base wage increases generated by the award negotiation process. The NZBR may be close to the mark in saying that employers see the award system "delivering...relatively low increases in nominal wages". However, in leaping from that observation to the suggestion that paying low award wages is a substantial basis for employer preference for national awards, the Business Roundtable's analysis strays from the mark.

To begin with, those few employers who do have complaints about the award wage increases show no greater inclination toward enterprise bargaining than the rest. Beyond that, the great majority of employers in the sample pay above the awards. Yet there was no relationship between preference for enterprise bargaining and current above award pay practices.

In short, base wages do not seem to be the issue. Many of these employers do not see unions as being as influential in wage setting as labour market and performance factors. Presumably, those opting for enterprise bargaining anticipate that unions negotiating at that level, with greater understanding of the company's circumstances, would be unlikely to push wages above levels dictated by these factors and the firm's ability to pay. One factor that did arise consistently in interviews as a point of discontent was that of compensation beyond base wages - penalty rates and industry allowances. About one-third of the employers expressed concerns in these areas. There was, however, no statistically significant relationship between this type of concern and preference for enterprise bargaining.

\section{Motivators for change}

If not discontent with the existing system, what then motivates half of the employers in the sample to opt for enterprise bargaining? It should be noted, incidentally, that the enterprise bargaining model described was not the "ideal" one from an employer's point of view. For example, it was specified that the union representing the firm's employees would be affiliated with a national union, and that the union would dispatch an advocate to represent the firm's employees in negotiations. Additionally, no fallback position was offered, no opportunity to opt back into a national award if things didn't work out as 
expected locally. Nonetheless, more than half opted for the enterprise system, and not because of widespread active disaffection with the national award system. Why then?

Two-thirds of the employers in the sample saw one or more advantages to their firm in moving to enterprise bargaining. The most commonly seen advantage was the ability to fashion employment terms tailored to the needs of the company. Among the other most commonly mentioned advantages were the related ones of greater company input into the bargaining process and control over bargaining outcomes, and greater input by the firm's employees into the bargaining process, presumably guiding positions taken on the union side of the bargaining table in a direction more in tune with company circumstances. Other perceived advantages mentioned most frequently were the opportunities for the development of closer working relationships between management and employees, and the standardisation of employment terms across the workforce.

There is a certain cohesion to the major advantages cited for enterprise bargaining, and it is supported by the strong statistical relationship between preference for enterprise bargaining and the belief that enterprise bargaining would also be advantageous for the firm's employees. The most persuasive advantages seen for enterprise bargaining were improved productivity, better union understanding of the company's needs and circumstances, better management-staff relations and cooperation, and employment terms tailored to company circumstances. It will be recalled that more than 80 percent of employers citing any of these advantages opted for enterprise bargaining over the national award system.

In essence, to collectively paraphrase those employers opting for the enterprise bargaining system, that system is seen as providing greater input into the bargaining process by both the employer and the firm's employees, thereby generating opportunities for a cooperative approach as well as employment terms tailored to the needs and circumstances of the parties, in turn resulting in productivity gains. Economically, pay supplements seen as counter-productive and irrelevant to the firm's circumstances may go, but the lowering of base pay rates does not appear to be a target. The enterprise bargaining system is seen by those employers who would prefer it as offering a positive contribution to the firm's and the employees' prosperity. These employers see the award system, by contrast, as neither contributing, nor particularly detracting, at least overtly, from the firm's performance.

On the other side of the coin, most of the employers in the sample saw one or more disadvantages to enterprise bargaining by comparison with the national award system. Most often mentioned were the potential damage to management-staff relations, the increased administrative workload and time commitment required for the labour relations function, isolation from the rest of the industry, the absence of pay guidelines, and the potential for targeting of companies by unions. Each of these disadvantages was mentioned by about 20 percent of the sample. Smaller numbers mentioned, in a variety of other ways, the intrusion of labour relations into the plant. Some of the motivations suggested by the NZBR analysis are apparent in this list, though the cynical tone of that analysis represents only one possible appraisal of these motivations. The most persuasive disadvantages seen in enterprise bargaining were the loss of informal managerial discretion, a higher degree of labour consciousness amongst the workforce, a greater union presence in the plant, greater demands on management time, and the potential damage to staff relations.

To again collectively paraphrase the thinking of those employers preferring to stay with the national award system, enterprise bargaining is seen as raising the profile and consciousness of labour relations in the workplace, distracting both managers and employees from their principal purpose in being together in the first place, damaging the existing camaraderie, and isolating the company from the rest of the industry and the labour market. In essence, the enterprise system is seen as more divisive, demanding and intrusive without sufficient concomitant benefits, whereas the national award system is seen as non-intrusive, non-demanding, and a buffer against divisiveness in the plant over 
labour relations matters. The fact that employers with a high percentage of workers unionised were more inclined to prefer the national award system seems consistent with their fear that a "them versus us" attitude would be likely to result from enterprise bargaining.

It is noteworthy that employers in the agricultural processing and related category, including fish processing and timber, were more likely to prefer enterprise bargaining than other employers, and that employers in the retailing and related category, most of whom were retailers, were less likely to prefer enterprise bargaining than other employers.

Two factors seem to be at work here. Firms in the agriculture and related category are amongst the most export oriented New Zealand firms, while the retail and related category would be amongst the NZEIC categories least exposed to the pressures of global competition, or in the words of the NZBR document, "still operating in protected markets". Second, firms in the agriculture and related category not only have the widest experience with plant agreements, but also have wide experience with regional awards. Those firms in the sample with experience under either form of localised document were significantly more likely to opt for enterprise bargaining. Likewise, those firms that reported presently involving unions in a range of decision making were more likely to opt for enterprise bargaining.

Exposure to external competitive pressures and exposure to local negotiations, then, appear to be two factors positively related to preference for enterprise bargaining. And of course, there may be an historical causal relationship between these two factors, in which case some might be tempted to argue that those most in need of decentralised arrangements can get them under existing legislation.

Finally, it is noteworthy that two-thirds of the employers in the sample would opt to use an outside advocate in enterprise bargaining from the outset. An additional onequarter were prepared to bring an advocate into the negotiations if necessary, though not initially.

A total of over 85 percent, then, were ready to use an outside advocate to represent them in negotiations. This perception of the way in which enterprise bargaining would work is clearly not the whimsical holding of hands contemplated by disciples of the unitarist school of labour relations. Rather, at least for those preferring enterprise bargaining, it is a pluralist approach to employer-employee cooperation within the framework of the inherently pluralist process of enterprise bargaining. For those opposed to a move to enterprise bargaining, the use of an advocate is a practical defensive measure, as pragmatically grounded as their opposition to enterprise bargaining.

The underlying theme here is, in fact, pragmatism. The employers in the sample divided about evenly on whether enterprise bargaining would be advantageous to their firms or disadvantageous, by comparison with the national award system. Half thought they saw positive opportunities; half saw any benefits outweighed by the intrusions inherent in the enterprise system. In both cases, those views appear to be pragmatic decisions based on their experiences and circumstances.

\section{References}

Committee of Inquiry into Industrial Democracy (1989) Report. Wellington.

McAndrew, Ian (1989) Bargaining structure and bargaining scope in New Zealand: the climate of employer opinion. New Zealand journal of industrial relations. 14(2): 149167. 
Marshall, Steve (1989) Attitudes and outcomes: wage bargaining in New Zealand. Address to the New Zealand Executive Management Society (4 October, 1989). Wellington, NZEF

New Zealand Business Roundtable (1986) New Zealand labour market reform: a submission in response to the green paper. Wellington, NZBR.

New Zealand Business Roundtable (1989) Review of the operation of the Labour Relations Act in the 1988/89 wage round. Wellington, NZBR.

New Zealand Council of Trade Unions (1989) Submission to the Industrial Democracy Committee of Inquiry. Wellington, NZCTU.

New Zealand Employers Federation (1986) The industrial relations green paper: an employer perspective. Wellington, NZEF.

Minister of Labour (1986) Industrial relations: a framework for review: summary of submissions. Wellington, Government Printer.

Minister of Labour (1990) Background statement: Labour Relations Act amendments. Wellington.

National Party (1990) New choices in industrial relations. Wellington.

Wood, Greg (1988) The Labour Relations Act and changes to the structure of bargaining. New Zealand journal of industrial relations. 13(2): 167-177. 